\title{
A single atom change "switches-on" the solar-to-energy conversion efficiency of Zn-porphyrin based dye sensitized solar cells to $10.5 \%$
}

\author{
Lydia Cabau, Challuri Vijay Kumar, Antonio Moncho, John N. Clifford , Núria
} López and Emilio Palomares

"Institute of Chemical Research of Catalonia (ICIQ), Avda. Països Catalans, 16, Tarragona, E-43007, Spain

${ }^{b}$ Catalan Institution for Research and Advanced Studies (ICREA), Passeig Lluís Companys,

\section{3, Barcelona E-08010, Spain}

In this work we report how crucial is the correct design of the porphyrin sensitizers in Dye Sensitized Solar Cells (DSSCs). Only a single atom changeswitches-on the efficiency from 2-3\% to over $10 \%$ under standard measurement conditions. We used the 2,1,3-benzothiadazole (BDT) group, as a $\pi$ conjugated linker, for the porphyrin LCVC01, a thiophene moiety for the porphyrin LCVCO2 and also the furan group for the LCVCO3 porphyrin, as molecular spacers between the BDT fragment and the molecule anchoring group, respectively. These three porphyrins were investigated for their application in DSSC devices. All the devices were characterized and found to achieve a record cell efficiency of $10.5 \%$ for LCVCO2 but only 3.84\% and $2.55 \%$ for LCVC01 and LCVC03 respectively. On one hand, the introduction of a thiophene, instead of a furan group, illustrates the importance of introducing a chemical group as a spacer, such as thiophene, between the BDT and the anchoring group. On the other hand, the selection of this group has to be correct because the change of a single atom increases the charge recombination rate and decreases the device performance. These changes can be rationalized by analyzing the dye dipoles and their interactions.

\section{Introduction}

Dye Sensitized Solar Cells (DSSCs) based on mesoporous $\mathrm{TiO}_{2}$ thin films and liquid electrolytes have already achieved solar-to-energy conversion efficiencies close to $13 \%, \underline{\mathrm{a}}$ value which is beyond that of the current state-of-the-art organic solar cells (OSCs) and close to the efficiencies reported for methyl-ammonium lead iodide perovskite based solar cells (MAPI) measured in forward bias (from short circuit, $I_{\mathrm{sc}}$, to open circuit voltage, $V_{\mathrm{oc}}$ ).

However, the use of liquid based red/ox electrolytes such as iodine/iodide or cobalt(II)/cobalt(III) has hampered their progress as a PV (photovoltaic) technology. 
Nonetheless, a recent application of these solar cells in the façade of a building has illustrated their real potential as a robust, colourful and transparent technology for solar-to-energy conversion. $\S$

Yet, there are several scientific issues that must be investigated further to achieve higher efficiencies by reducing the device losses that limit the voltage in the DSSC, and approach the maximum theoretical efficiency that is close to $20 \%$. 2 As shown in Fig. 1, porphyrin based DSSCs are capable of reaching high photocurrents but $V_{\mathrm{oc}}$ is low compared, for example, with OSC and MAPI solar cells.

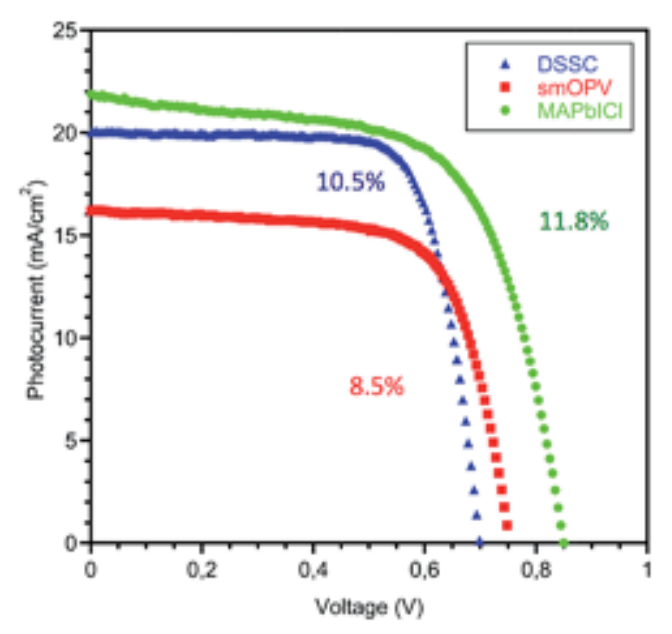

Fig. 1 IV curves under 1 sun-simulated 1.5 AMG conditions for a LCVC02 porphyrin DSSC (this work; blue triangles), a MAPI solar cell (green dots) and an OSC based small molecule DR3TBDT:PC ${ }_{70} \mathrm{BM}$ (red squares). All devices were made at ICIQ.

In 2010, a landmark paper by Yeh and collaborators described the synthesis of so-called "push-pull approach" Zn-porphyrins that lead to a remarkable increase in the solar-toelectrical conversion efficiency in porphyrin based DSSCs from 5-6\% to $11 \%$. Later, this efficiency was increased by using a more sophisticated molecular design of the porphyrin structure and a world-record efficiency of $12.3 \%$ (ref. 4) was obtained. Since then, the synthesis and use of asymmetric porphyrins have increased exponentially $\underline{\underline{s}}$ but little attention has been paid to the device function-porphyrin structure relationship through the detailed analysis of the interfacial charge recombination reactions ${ }^{5.6 .6}$ or the porphyrin structure. Indeed, it has been more difficult to understand what are the reasons for subtle modifications in the porphyrin structure leading to substantial decrease in the $V_{\text {oc }}$ and, hence, in the cell efficiency under operation conditions and, thus, not many examples of Zn-based porphyrins can be found in the scientific literature that overpass the $10 \%$ efficiency value. 
Herein, we have focussed, not only on the design of a push-pull porphyrin for efficient DSSCs but also on the integral evaluation of the reactions that limit the device $V_{\text {oc }}$, and thus, the efficiency.

Fig. 2 illustrates the three porphyrins synthesized in this work and used to prepare DSSCs.

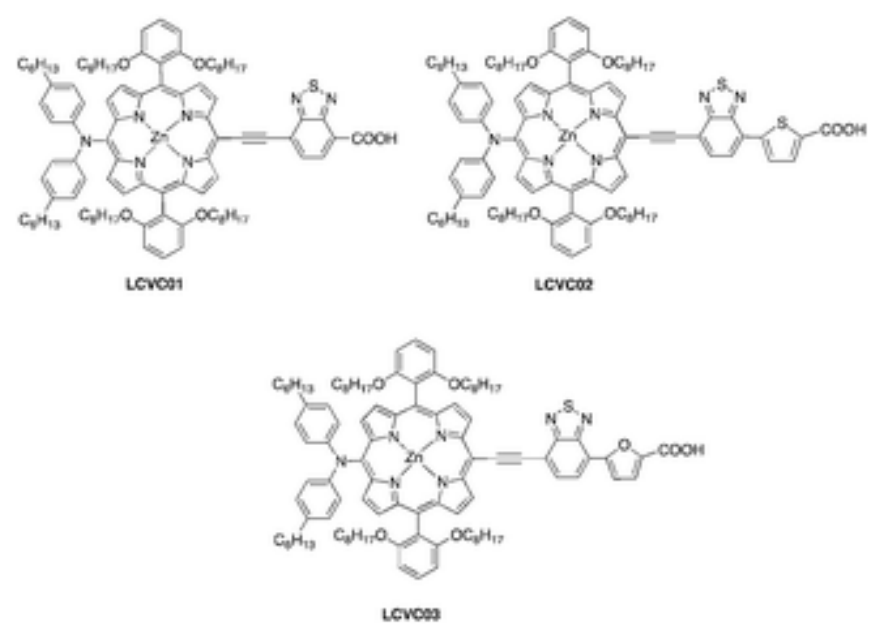

Fig. 2 The molecular structures of porphyrins in LCVC01, LCVC02 and LCVC03 dyes.

\section{Experimental section}

\subsection{Materials}

$N, N$-Dimethylformamide (DMF) and THF were distilled before use. $\mathrm{Pd}^{\mathrm{II}}(\mathrm{dppf}) \mathrm{Cl}_{2}, N$ bromosuccinimide (NBS), potassium carbonate, 4-tert-butylpyridine (TBP), (5formylthiophen-2-yl) boronic acid, (5-formylfuran-2-yl) boronic acid, TBAF, $\mathrm{Pd}_{2}(\mathrm{dba})_{3}$ and $\mathrm{AsPh}_{3}$ were purchased from Sigma-Aldrich.

\subsection{Instruments}

The UV-visible absorption was measured using a $1 \mathrm{~cm}^{2}$ path-length quartz cell on a Shimadzu@ UV 1700 spectrophotometer. The steady state fluorescence spectra were recorded using a Spex model Fluoromax-3 spectro-fluorometer using a $1 \mathrm{~cm}^{2}$ quartz square. The ${ }^{1} \mathrm{H}-$ NMR spectra were measured at $300 \mathrm{MHz}$ on a Bruker 300 Avance NMR spectrometer with $\mathrm{X}$-Win NMR software. The ${ }^{1} \mathrm{H}$ spectra were referenced to tetramethylsilane. The ESI-MS (Electro Spray Ionisation Mass Spectra) were recorded on a Water Quattro micro (Water, Inc., USA). The cyclic voltammetry experiments were recorded with a PC-controlled $\mathrm{CH}$ instruments $@$ model CHI620C electrochemical analyser. 
Laser Transient Absorption Spectroscopy (L-TAS), charge extraction (CE) and transient photovoltage (TPV) were carried out as detailed previously. ${ }^{?}$

\subsection{Synthesis and characterization}

The porphyrin intermediate to synthesize LCVC01, LCVC02 and LCVC03 was prepared according to the literature $; \underline{4}$ Scheme 1 .
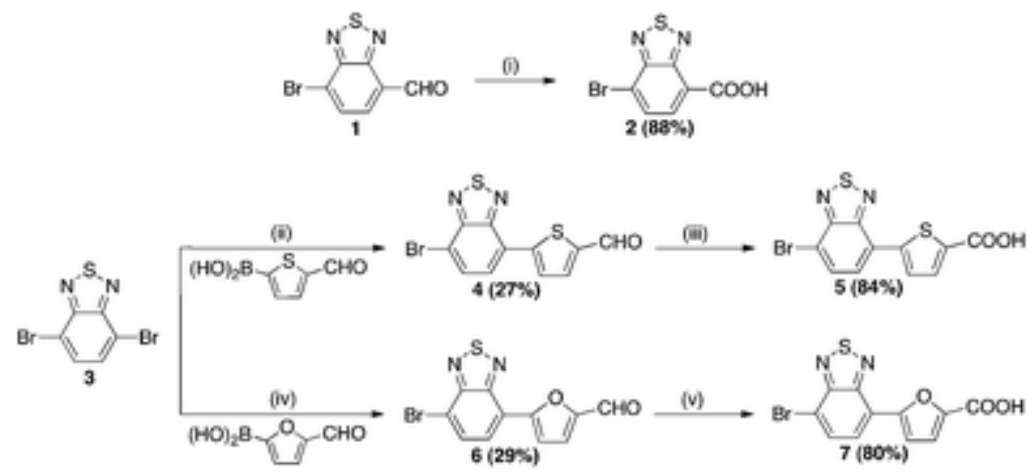

Scheme 1 The synthesis route to the acceptor moieties. Reaction conditions: (i) $\mathrm{NaClO}_{2}$, sulfamic acid aqueous, acetone, $4 \mathrm{~h}, \mathrm{RT}$; (ii) $\mathrm{Pd}$ "(dppf) $\mathrm{Cl}_{2}, 2 \mathrm{M} \mathrm{K}_{2} \mathrm{CO}_{3}$ aqueous solution, THF, $2 \mathrm{~h}, 76^{\circ} \mathrm{C}$; (iii) $\mathrm{NaClO}_{2}$, sulfamic acid aqueous, acetone, $4 \mathrm{~h}, \mathrm{RT}$; (iv) Pd"(dppf) $\mathrm{Cl}_{2}, 2 \mathrm{M} \mathrm{K}_{2} \mathrm{CO}_{3}$ aqueous solution, THF, $2 \mathrm{~h}, 76$ ${ }^{\circ} \mathrm{C}$; (v) $\mathrm{NaClO}_{2}$, sulfamic acid aqueous, acetone, $4 \mathrm{~h}$, RT (room temperature).

Synthesis of 7-bromobenzo[c][1,2,5]thiadiazole-4-carboxylic acid 2. A solution at 0 ${ }^{\circ} \mathrm{C}$ of 7-bromobenzo[c][1,2,5]thiadiazole-4-carbaldehyde $(0.1 \mathrm{~g}, 0.41 \mathrm{mmol})$ in acetone $(70$ $\mathrm{mL})$ and $\mathrm{NaClO}_{2}(0.109 \mathrm{~g}, 1.21 \mathrm{mmol})$ was added slowly. Then, a solution of sulfamic acid $(0.117 \mathrm{~g}, 1.21 \mathrm{mmol})$ in Milli-Q-grade deionized water $(8 \mathrm{~mL})$ was added and the solution was stirred at room temperature for $4 \mathrm{~h}$. After this, the reaction was quenched with $\mathrm{HCl}(0.1$ $\mathrm{M}, 250 \mathrm{~mL}$ ) and the mixture was extracted with $\mathrm{CHCl}_{3}$. The combined extracts were washed with water and dried over anhydrous $\mathrm{MgSO}_{4}$. The solvent was removed under reduced pressure to give the desired product (white solid) $\left(0.093 \mathrm{~g}, 88 \%\right.$ yield). ${ }^{1} \mathrm{H} \mathrm{NMR}\left(\mathrm{CDCl}_{3}, 400\right.$ MHz) $\delta_{\mathrm{H}}: 8.45(\mathrm{~d}, J=7.7 \mathrm{~Hz}, 1 \mathrm{H}) ; 8.05(\mathrm{~d}, J=7.7 \mathrm{~Hz}, 1 \mathrm{H})$.

\section{Synthesis of 5-(7-bromobenzo[c][1,2,5]thiadiazol-4-yl)thiophene-2-carbaldehyde} (4). In a Schlenk flask, 3 (0.5 g, $1.70 \mathrm{mmol})$, (5-formylthiophen-2-yl) boronic acid (0.268 g, $1.70 \mathrm{mmol}), \mathrm{Pd}^{\mathrm{II}}(\mathrm{dppf}) \mathrm{Cl}_{2}(0.056 \mathrm{~g}, 0.0765 \mathrm{mmol})$ and $50 \mathrm{~mL}$ of THF were added together and the mixture was degassed. Then the solution was stirred at room temperature for 30 minutes. After this period $7 \mathrm{~mL}$ of $2 \mathrm{M} \mathrm{K}_{2} \mathrm{CO}_{3}$ was added and the mixture was degassed 
again. Thereafter, the mixture was heated up to $76{ }^{\circ} \mathrm{C}$ for 2 hours, cooled at room temperature and extracted with $\mathrm{Et}_{2} \mathrm{O}$, upon addition of water, and washed with brine. Finally, the crude sample was purified by column chromatography using hexane/ethyl acetate ( $\mathrm{v}: \mathrm{v}: 8: 2)$ as a solvent to give us the desired product (yellow solid) $\left(150 \mathrm{mg}, 27 \%\right.$ yield). ${ }^{1} \mathrm{H} \mathrm{NMR}\left(\mathrm{CDCl}_{3}\right.$, $400 \mathrm{MHz}) \delta_{\mathrm{H}}: 9.95(\mathrm{~s}, 1 \mathrm{H}) ; 8.25(\mathrm{~d}, J=4.0 \mathrm{~Hz}, 1 \mathrm{H}) ; 8.06(\mathrm{~d}, J=7.7 \mathrm{~Hz}, 1 \mathrm{H}) ; 8.00(\mathrm{dd}, J=$ $7.7 \mathrm{~Hz}, 21.0 \mathrm{~Hz} 2 \mathrm{H}) ; 7.93(\mathrm{~d}, J=4.0 \mathrm{~Hz}, 1 \mathrm{H}) .{ }^{13} \mathrm{C}$ NMR $(100 \mathrm{MHz}$, THF-d8, ppm) $\delta$ : 183.18; $162.87 ; 160.35 ; 153.92 ; 145.65 ; 136.99 ; 134.36 ; 132.99 ; 129.00 ; 128.05 ; 115.27$. MS-ESI $(m / z):[\mathrm{M}-\mathrm{H}]$ calculated for $\mathrm{C}_{11} \mathrm{H}_{4} \mathrm{~N}_{2} \mathrm{BrN}_{2} \mathrm{OS}_{2}$ : 322.8954 ; found: 322.8958 .

\section{Synthesis of 5-(7-bromobenzo[ $c][1,2,5]$ thiadiazol-4-yl)thiophene-2-carboxylic acid} (5). $\mathrm{NaClO}_{2}(0.124 \mathrm{~g}, 1.38 \mathrm{mmol})$ was added slowly at $0{ }^{\circ} \mathrm{C}$ to a solution of 5-(7bromobenzo[c][1,2,5]thiadiazol-4-yl)thiophene-2-carbaldehyde and 4 (150 mg; $0.46 \mathrm{mmol})$ in acetone $(100 \mathrm{~mL})$. Then, a solution of sulfamic acid $(0.134 \mathrm{~g} ; 1.38 \mathrm{mmol})$ in Milli-Q-grade deionized water $(10 \mathrm{~mL})$ was added to proceed at room temperature for $4 \mathrm{~h}$. Subsequently, the reaction was quenched with $\mathrm{HCl}(0.1 \mathrm{M}, 250 \mathrm{~mL})$ and the mixture was extracted with $\mathrm{CHCl}_{3}$. The combined extracts were washed with water and dried over anhydrous $\mathrm{MgSO}_{4}$. The solvent was removed under reduced pressure to give us the desired product (white solid) $\left(0.131 \mathrm{~g}, 84 \%\right.$ yield). ${ }^{1} \mathrm{H}$ NMR (DMSO-d $\left.{ }_{6}, 400 \mathrm{MHz}\right) \delta_{\mathrm{H}}: 8.12(\mathrm{~m}, 3 \mathrm{H}) ; 7.82(\mathrm{~d}, J=4.0 \mathrm{~Hz}$, 1H). ${ }^{13} \mathrm{C}$ NMR (100 MHz, DMSO-d $\left.\mathrm{d}_{6}, \mathrm{ppm}\right) \delta: 162.85 ; 152.94 ; 150.82 ; 143.52 ; 135.81$; $133.44 ; 132.49 ; 127.95 ; 127.18 ; 125.07 ; 113.22$. MS-ESI $(\mathrm{m} / \mathrm{z}):[\mathrm{M}-\mathrm{H}]$ calculated for $\mathrm{C}_{11} \mathrm{H}_{4} \mathrm{~N}_{2} \mathrm{BrN}_{2} \mathrm{O}_{2} \mathrm{~S}_{2}: 338.8898$; found: 338.8903 .

Synthesis of 5-(7-bromobenzo[c][1,2,5]thiadiazol-4-yl)furan-2-carbaldehyde (6). In a Schlenk flask 3 (0.5 g, $1.70 \mathrm{mmol})$, (5-formylfuran-2-yl) boronic acid $(0.237 \mathrm{~g}, 1.70 \mathrm{mmol})$, $\mathrm{Pd}^{\mathrm{II}}(\mathrm{dppf}) \mathrm{Cl}_{2}(0.056 \mathrm{~g}, 0.0765 \mathrm{mmol})$ and $50 \mathrm{~mL}$ of THF were added and the mixture was degassed. Following the degasification, the solution was stirred at room temperature for 30 minutes. Thereafter, $7 \mathrm{~mL}$ of $2 \mathrm{M} \mathrm{K}_{2} \mathrm{CO}_{3}$ were added and the mixture was degassed again. Then the mixture was heated up to $76^{\circ} \mathrm{C}$ for 2 hours. After cooling at room temperature we added water and the solution was extracted with $\mathrm{Et}_{2} \mathrm{O}$ and washed with brine. Then the crude sample was purified by column chromatography using hexane/DCM (v: v: $8: 2)$ as a solvent to give us the desired product (yellow solid) $\left(0.160 \mathrm{~g}, 29 \%\right.$ yield). ${ }^{1} \mathrm{H} \mathrm{NMR}\left(\mathrm{CDCl}_{3}, 400\right.$ MHz) $\delta_{\mathrm{H}}: 9.72(\mathrm{~s}, 1 \mathrm{H}) ; 8.14(\mathrm{~d}, J=7.7 \mathrm{~Hz}, 1 \mathrm{H}) ; 7.94(\mathrm{~d}, J=7.7 \mathrm{~Hz}, 1 \mathrm{H}) ; 7.87(\mathrm{~d}, J=3.6 \mathrm{~Hz}$, $1 \mathrm{H}) ; 7.41(\mathrm{~d}, J=3.6 \mathrm{~Hz}, 1 \mathrm{H}) ;{ }^{13} \mathrm{C} \mathrm{NMR}\left(100 \mathrm{MHz}, \mathrm{CDCl}_{3}, \mathrm{ppm}\right) \delta: 177.71 ; 154.39 ; 154.017$; $152.31 ; 150.92 ; 132.45 ; 126.50 ; 123.88 ; 121.50 ; 115.65 ; 114.89 \mathrm{MS}-\mathrm{ESI}(\mathrm{m} / \mathrm{z}):[\mathrm{M}+$ $\mathrm{Na}]^{+}$calculated for $\mathrm{C}_{11} \mathrm{H}_{5} \mathrm{~N}_{2} \mathrm{BrN}_{2} \mathrm{NaO}_{2} \mathrm{~S}$ : 330.9147; found: 330.9137 .

Synthesis of 5-(7-bromobenzo[c][1,2,5]thiadiazol-4-yl)furan-2-carboxylic acid (7). A solution at $0{ }^{\circ} \mathrm{C}$ of 5-(7-bromobenzo[ $\left.c\right][1,2,5]$ thiadiazol-4-yl)furan-2-carbaldehyde $6(0.160$ $\mathrm{g} ; 0.51 \mathrm{mmol})$ in acetone $(110 \mathrm{~mL})$ and $\mathrm{NaClO}_{2}(0.140 \mathrm{~g}, 1.55 \mathrm{mmol})$ was added slowly. Then, a solution of sulfamic acid $(0.151 \mathrm{~g}, 1.55 \mathrm{mmol})$ in Milli-Q-grade deionized water (10 $\mathrm{mL}$ ) was added and the solution was then stirred at room temperature for $4 \mathrm{~h}$. After the 4 hours, the reaction was quenched with $\mathrm{HCl}(0.1 \mathrm{M}, 250 \mathrm{~mL})$ and the mixture was extracted with $\mathrm{CHCl}_{3}$. The combined extracts were washed with water and dried over anhydrous $\mathrm{MgSO}_{4}$. The solvent was removed under reduced pressure to give us the desired product (yellow solid) $\left(0.133 \mathrm{~g}, 80 \%\right.$ yield). ${ }^{1} \mathrm{H}$ NMR (DMSO-d $\left.6400 \mathrm{MHz}\right) \delta_{\mathrm{H}}: 8.12(\mathrm{~d}, J=7.7 \mathrm{~Hz}$, $1 \mathrm{H}) ; 7.99(\mathrm{~d}, J=7.7 \mathrm{~Hz}, 1 \mathrm{H}) ; 7.69(\mathrm{~d}, J=3.6 \mathrm{~Hz}, 1 \mathrm{H}) ; 7.42(\mathrm{~d}, J=3.6 \mathrm{~Hz}, 1 \mathrm{H}) ;{ }^{13} \mathrm{C} \mathrm{NMR}$ (100 MHz, DMSO-d ${ }_{6}$, ppm) $\delta: 159.13 ; 153.00 ; 151.44 ; 149.83 ; 144.88 ; 132.54 ; 125.28$; $120.91 ; 119.82 ; 113.90 ; 113.45$. MS-ESI $(m / z):[\mathrm{M}-\mathrm{H}]$ calculated for $\mathrm{C}_{11} \mathrm{H}_{4} \mathrm{~N}_{2} \mathrm{BrN}_{2} \mathrm{O}_{3} \mathrm{~S}$ : 322.9126; found: 322.9137 .

Synthesis of LCVC01. To a solution of [5-bis(4-hexylphenyl)amino-15(triisopropylsily)ethynyl-10,20-bis(2,6-di-octooxyphenyl)porphirinato]zinc(II) 8 (240 mg, $0.154 \mathrm{mmol})$ in dry THF $(20 \mathrm{~mL})$ we added $1 \mathrm{M}$ TBAF $(0.78 \mathrm{~mL})$ in THF. The solution was stirred at $23{ }^{\circ} \mathrm{C}$ for 30 min under $\mathrm{N}_{2}$. The mixture was quenched with $\mathrm{H}_{2} \mathrm{O}$ and then extracted 
with $\mathrm{CH}_{2} \mathrm{Cl}_{2}$. The organic layer was dried using anhydrous $\mathrm{MgSO}_{4}$ and the solvent was removed under reduced pressure. The residue and the 7-bromobenzo[c][1,2,5]thiadiazole-4carboxylic acid 2 (190 mg, 0.76) were dissolved in a mixture of dry THF (36 mL) and $\mathrm{NEt}_{3}(7$ $\mathrm{mL}$ ) and the solution was degassed with $\mathrm{N}_{2}$ for $10 \mathrm{~min}$. Then, $\mathrm{Pd}_{2}(\mathrm{dba})_{3}(42 \mathrm{mg}, 0.046 \mathrm{mmol})$ and $\mathrm{AsPh}_{3}(100 \mathrm{mg}, 0.30 \mathrm{mmol})$ were added to the mixture. The solution was refluxed for 4 hours under $\mathrm{N}_{2}$. The solvent was removed under reduced pressure. After that, the residue was purified by column chromatography (silica gel) using $\mathrm{DCM} / \mathrm{CH}_{3} \mathrm{OH}=20 / 1$ as the eluent. Recrystallization from $\mathrm{CH}_{3} \mathrm{OH} / \mathrm{ether}$ gave LCVC01 (180 mg, 74\%). ${ }^{1} \mathrm{H}$ NMR (THF-d8, 400 MHz) $\delta_{\mathrm{H}}: 9.97(\mathrm{~d}, J=4.6 \mathrm{~Hz}, 2 \mathrm{H}) ; 9.04(\mathrm{~d}, J=4.6 \mathrm{~Hz}, 2 \mathrm{H}) ; 8.81(\mathrm{~d}, J=4.6 \mathrm{~Hz}, 2 \mathrm{H}) ; 8.55$ $(\mathrm{d}, J=4.6 \mathrm{~Hz}, 2 \mathrm{H}) ; 8.54(\mathrm{~s}, 1 \mathrm{H}) ; 8.30(\mathrm{~d}, J=7.6 \mathrm{~Hz}, 1 \mathrm{H}) ; 7.67(\mathrm{t}, J=8.4 \mathrm{~Hz}, 2 \mathrm{H}) ; 7.20$ $(\mathrm{d}, J=8.4 \mathrm{~Hz}, 4 \mathrm{H}) ; 7.04(\mathrm{~d}, J=8.4 \mathrm{~Hz}, 4 \mathrm{H}) ; 6.92(\mathrm{~d}, J=8.4 \mathrm{~Hz}, 4 \mathrm{H}) ; 3.87(\mathrm{t}, J=6.3 \mathrm{~Hz}$, $8 \mathrm{H}) ; 2.47(\mathrm{t}, J=7.4 \mathrm{~Hz}, 4 \mathrm{H}) ; 1.58-1.51(\mathrm{~m}, 4 \mathrm{H}) ; 1.36-1.27(\mathrm{~m}, 12 \mathrm{H}) ; 1.00-0.57$ (m, $66 \mathrm{H})$ (Scheme 2).

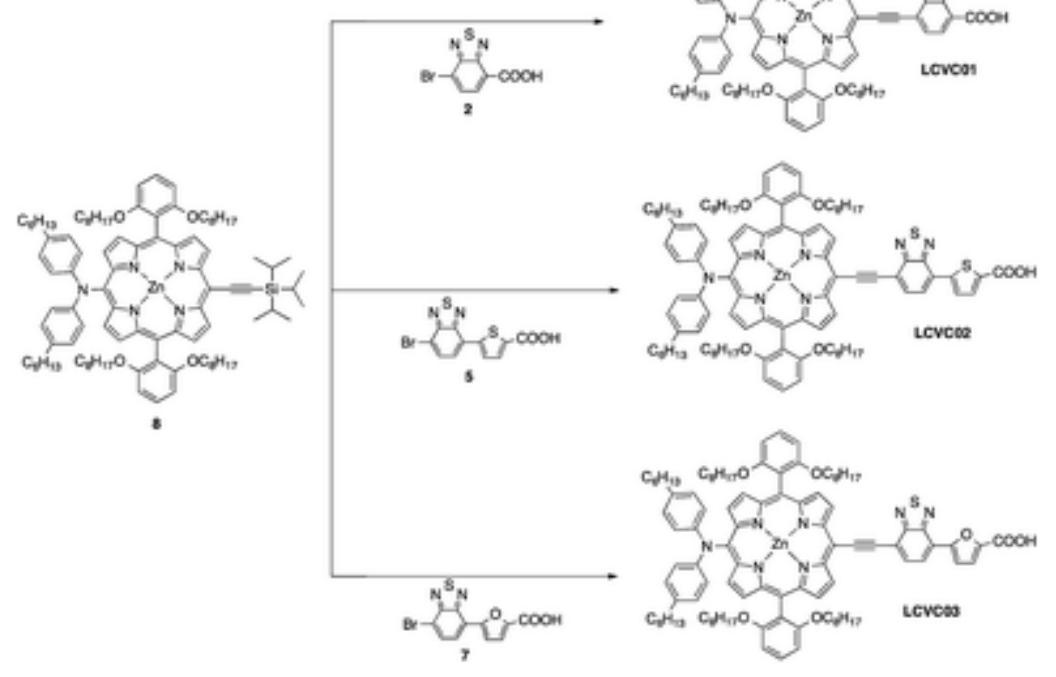

Scheme 2 Synthesis route to the LCVC01, LCVCO2 and LCVC03 dyes (reaction conditions: (i) 1 M TBAF in THF, THF, 30 minutes, $23^{\circ} \mathrm{C}, 2, \mathrm{NEt}_{3}, \mathrm{Pd}_{2}\left(\mathrm{dba}_{3}, \mathrm{AsPh}_{3}\right.$, THF, $4 \mathrm{~h}$, reflux; (ii) TBAF $1 \mathrm{M}$ in THF, THF, 30 minutes, $23^{\circ} \mathrm{C}, 5, \mathrm{NEt}_{3}, \mathrm{Pd}_{2}(\mathrm{dba})_{3}, \mathrm{AsPh}_{3}, \mathrm{THF}, 4 \mathrm{~h}$, reflux; and (iii) TBAF $1 \mathrm{M}$ in THF, THF, 30 minutes, $23^{\circ} \mathrm{C}, 7, \mathrm{NEt}_{3}, \mathrm{Pd}_{2}(\mathrm{dba})_{3}, \mathrm{AsPh}_{3}, \mathrm{THF}, 4 \mathrm{~h}$, reflux).

Synthesis of LCVC02. To a solution of [5-bis(4-hexylphenyl)amino-15-(triisopropylsily)ethynyl10,20-bis(2,6-di-octooxyphenyl)porphirinato]zinc(II) 8 (165 mg, $0.106 \mathrm{mmol}$ ) in dry THF (15 mL) was added $1 \mathrm{M}$ TBAF $(0.54 \mathrm{~mL})$ in THF. The solution was stirred at $23^{\circ} \mathrm{C}$ for 30 min under $\mathrm{N}_{2}$. The mixture was quenched with $\mathrm{H}_{2} \mathrm{O}$ and then extracted with $\mathrm{CH}_{2} \mathrm{Cl}_{2}$. The organic layer was dried using anhydrous $\mathrm{MgSO}_{4}$ and the solvent was removed under reduced pressure. The residue and 5-(7bromobenzo[c][1,2,5]thiadiazol-4-yl)thiophene-2-carboxylic acid 5 (180 mg, $0.53 \mathrm{mmol}$ ) were dissolved in a mixture of dry THF $(30 \mathrm{~mL})$ and $\mathrm{NEt}_{3}(4.8 \mathrm{~mL})$ and the solution was degassed with 
dinitrogen for $10 \mathrm{~min}$. Then, $\mathrm{Pd}_{2}(\mathrm{dba})_{3}(29 \mathrm{mg}, 0.031 \mathrm{mmol})$ and $\mathrm{AsPh}_{3}(71 \mathrm{mg}, 0.212 \mathrm{mmol})$ were added to the mixture. The solution was refluxed for 4 hours under $\mathrm{N}_{2}$. The solvent was removed under reduced pressure. Then, the residue was purified by column chromatography (silica gel) using $\mathrm{DCM} / \mathrm{CH}_{3} \mathrm{OH}=20 / 1$ as the eluent. Recrystallization from $\mathrm{CH}_{3} \mathrm{OH} /$ ether gave LCVCO2 (115 mg, $66 \%) .{ }^{1} \mathrm{H}$ NMR (THF-d8, $\left.400 \mathrm{MHz}\right) \delta_{\mathrm{H}}: 9.96(\mathrm{~d}, J=4.6 \mathrm{~Hz}, 2 \mathrm{H}) ; 9.03(\mathrm{~d}, J=4.6 \mathrm{~Hz}, 2 \mathrm{H}) ; 8.80(\mathrm{~d}, J=4.6 \mathrm{~Hz}$, $2 \mathrm{H}) ; 8.55(\mathrm{~d}, J=4.6 \mathrm{~Hz}, 2 \mathrm{H}) ; 8.27(\mathrm{~s}, 2 \mathrm{H}) ; 8.24(\mathrm{~d}, J=4.0 \mathrm{~Hz}, 1 \mathrm{H}) ; 7.84(\mathrm{~d}, J=4.0 \mathrm{~Hz}, 1 \mathrm{H}) ; 7.65(\mathrm{t}, J=8.4$ $\mathrm{Hz}, 2 \mathrm{H}) ; 7.19(\mathrm{~d}, J=8.4 \mathrm{~Hz}, 4 \mathrm{H}) ; 7.02(\mathrm{~d}, J=8.4 \mathrm{~Hz}, 4 \mathrm{H}) ; 6.91(\mathrm{~d}, J=8.0 \mathrm{~Hz}, 4 \mathrm{H}) ; 3.85(\mathrm{t}, J=6.4 \mathrm{~Hz}, 8 \mathrm{H})$; $2.46(\mathrm{t}, J=7.3 \mathrm{~Hz}, 4 \mathrm{H}) ; 1.59-1.51(\mathrm{~m}, 4 \mathrm{H}) ; 1.28(\mathrm{~m}, 12 \mathrm{H}) ; 0.97-0.55(\mathrm{~m}, 66 \mathrm{H}) .^{13} \mathrm{C} \mathrm{NMR}(100 \mathrm{MHz}$, THFd8, ppm) $\delta: 160.78 ; 156.76 ; 153.02 ; 152.11 ; 151.53 ; 151.28 ; 151.02 ; 134.90 ; 132.57 ; 132.06 ; 131.27$; $130.81 ; 130.42 ; 130.34 ; 129.16 ; 128.21 ; 127.29 ; 122.39 ; 121.49 ; 121.46 ; 115.27 ; 105.71 ; 68.73$; $35.98 ; 32.54 ; 32.36 ; 30.45 ; 29.58 ; 29.50 ; 29.40 ; 25.98 ; 23.32 ; 23.10 ; 14.23 ; 14.10 . \mathrm{MS}-\mathrm{ESI}(\mathrm{m} / \mathrm{z}):[\mathrm{M}+$ $\mathrm{Na}]^{+}$calculated for $\mathrm{C}_{101} \mathrm{H}_{121} \mathrm{~N}_{7} \mathrm{NaO}_{6} \mathrm{~S}_{2} \mathrm{Zn}: 1678.8003$; found: 1678.7963 .

Synthesis of LCVC03. To a solution of [5-bis(4-hexylphenyl)amino-15-(triisopropylsily)ethynyl10,20-bis(2,6-di-octooxyphenyl)porphirinato]zinc(II) 8 (150 mg, $0.09 \mathrm{mmol}$ ) in dry THF (15 mL) was added $1 \mathrm{M}$ TBAF $(0.50 \mathrm{~mL})$ in THF. The solution was stirred at $23^{\circ} \mathrm{C}$ for 30 min under $\mathrm{N}_{2}$. The mixture was quenched with $\mathrm{H}_{2} \mathrm{O}$ and then extracted with $\mathrm{CH}_{2} \mathrm{Cl}_{2}$. The organic layer was dried using anhydrous $\mathrm{MgSO}_{4}$ and the solvent was removed under reduced pressure. The residue and 5-(7bromobenzo[c][1,2,5]thiadiazol-4-yl)furan-2-carboxylic acid $\mathbf{7}(146 \mathrm{mg}, 0.45)$ were dissolved in a mixture of dry THF (24 mL) and $\mathrm{NEt}_{3}(4 \mathrm{~mL})$ and the solution was degassed with $\mathrm{N}_{2}$ for $10 \mathrm{~min}$. Then, $\mathrm{Pd}_{2}(\mathrm{dba})_{3}(24 \mathrm{mg}, 0.026 \mathrm{mmol})$ and $\mathrm{AsPh}_{3}(60 \mathrm{mg}, 0.18 \mathrm{mmol})$ were added to the mixture. The solution was refluxed for 4 hours under $\mathrm{N}_{2}$. The solvent was removed under reduced pressure. The residue was purified by column chromatography (silica gel) using $\mathrm{DCM} / \mathrm{CH}_{3} \mathrm{OH}=20 / 1$ as the eluent. Recrystallization from $\mathrm{CH}_{3} \mathrm{OH}$ /ether gave LCVCO3 (112 mg, 76\%). ${ }^{1} \mathrm{H}$ NMR (THF-d8, $400 \mathrm{MHz}$ ) $\delta_{\mathrm{H}}: 9.80$ $(\mathrm{d}, J=4.6 \mathrm{~Hz}, 2 \mathrm{H}) ; 8.87(\mathrm{~d}, J=4.6 \mathrm{~Hz}, 2 \mathrm{H}) ; 8.63(\mathrm{~d}, J=4.6 \mathrm{~Hz}, 2 \mathrm{H}) ; 8.38(\mathrm{~d}, J=4.6 \mathrm{~Hz}, 2 \mathrm{H}) ; 8.20$ (dd, $J=$ $7.7 \mathrm{~Hz}, 21.0 \mathrm{~Hz} 2 \mathrm{H}) ; 7.76(\mathrm{~d}, J=3.6 \mathrm{~Hz}, 1 \mathrm{H}) ; 7.49(\mathrm{t}, J=8.3 \mathrm{~Hz}, 2 \mathrm{H}) ; 7.24(\mathrm{~d}, J=3.6 \mathrm{~Hz}, 1 \mathrm{H}) ; 7.03(\mathrm{~d}, J=$ $8.7 \mathrm{~Hz}, 4 \mathrm{H}) ; 6.86(\mathrm{~d}, J=8.7 \mathrm{~Hz}, 4 \mathrm{H}) ; 6.75(\mathrm{~d}, J=8.7 \mathrm{~Hz}, 4 \mathrm{H}) ; 3.70(\mathrm{t}, J=6.5 \mathrm{~Hz}, 8 \mathrm{H}) ; 2.29(\mathrm{t}, J=7.4 \mathrm{~Hz}$, $4 \mathrm{H}) ; 1.40-1.31(\mathrm{~m}, 4 \mathrm{H}) ; 1.12(\mathrm{~m}, 12 \mathrm{H}) ; 0.82-0.46(\mathrm{~m}, 66 \mathrm{H}){ }^{13} \mathrm{C}$ NMR (100 MHz, THF-d8, ppm) $\delta$ : $160.78 ; 156.75 ; 153.03 ; 152.10 ; 151.88 ; 151.53 ; 151.28 ; 151.02 ; 134.90 ; 132.58 ; 132.05 ; 131.32$; $130.82 ; 130.34 ; 129.16 ; 125.75 ; 123.94 ; 122.40 ; 121.49 ; 115.27 ; 114.39 ; 105.17 ; 68.72 ; 35.98 ; 32.54$; $32.36 ; 29.91 ; 29.60 ; 29.50 ; 29.40 ; 25.98 ; 23.32 ; 23.10 ; 14.23 ; 14.10 . \mathrm{MS}-\mathrm{ESI}(\mathrm{m} / \mathrm{z}):[\mathrm{M}]^{+}$calculated for $\mathrm{C}_{101} \mathrm{H}_{121} \mathrm{~N}_{7} \mathrm{O}_{7} \mathrm{SZn}: 1639.8334$; found: 1639.8365 .

\subsection{Solar cell preparation}

The working and counter electrodes consisted of mesoporous $\mathrm{TiO}_{2}$ and thermalized platinum films, respectively, deposited onto F-doped tin oxide (FTO, Pilkington Glass Inc. with $15 \Omega$ $\mathrm{sq}^{-1}$ sheet resistance) conducting glass substrates. Two different types of $\mathrm{TiO}_{2}$ films were utilized depending on the measurements being performed. On one hand, highly transparent thin films ( $8 \mu \mathrm{m}$ thick) were utilized for L-TAS measurements. On the other hand, efficient DSC devices were made using $14 \mu \mathrm{m}$ thick films consisting of $20 \mathrm{~nm} \mathrm{TiO}_{2}$ nanoparticles 
(Dyesol@ paste) and a scatter layer of $4 \mu \mathrm{m}$ of $400 \mathrm{~nm} \mathrm{TiO}$ particles (CCIC, HPW-400). Prior to the deposition of the $\mathrm{TiO}_{2}$ paste the conducting glass substrates were immersed in a solution of $\mathrm{TiCl}_{4}(40 \mathrm{mM})$ for 30 minutes and then dried. The $\mathrm{TiO}_{2}$ nanoparticle paste was deposited onto a conducting glass substrate using the screen printing technique. The $\mathrm{TiO}_{2}$ electrodes were gradually heated under an airflow at $325^{\circ} \mathrm{C}$ for $5 \mathrm{~min}, 375^{\circ} \mathrm{C}$ for $5 \mathrm{~min}$, $450{ }^{\circ} \mathrm{C}$ for $15 \mathrm{~min}$ and $500{ }^{\circ} \mathrm{C}$ for $15 \mathrm{~min}$. The heated $\mathrm{TiO}_{2}$ electrodes were immersed again in a solution of $\mathrm{TiCl}_{4}(40 \mathrm{mM})$ at $70{ }^{\circ} \mathrm{C}$ for $30 \mathrm{~min}$ and then washed with ethanol. The electrodes were heated again at $500{ }^{\circ} \mathrm{C}$ for $30 \mathrm{~min}$ and cooled before dye adsorption. The active area for devices was $0.16 \mathrm{~cm}^{2}$. The counter electrode was made by spreading a $5 \mathrm{mM}$ solution of $\mathrm{H}_{2} \mathrm{PtCl}_{6}$ in isopropyl alcohol onto a conducting glass substrate with a small hole to allow the introduction of the liquid electrolyte using a vacuum, followed by heating at $400{ }^{\circ} \mathrm{C}$ for 15 minutes. All the films were sensitized in dye solutions at a concentration of $0.125 \mathrm{mM}$ in ethanol containing an excess of chenodeoxycholic acid. The films were immersed overnight at room temperature. The sensitized electrodes were washed with ethanol and dried under air. Finally, the working and counter electrodes were sandwiched together using a thin thermoplastic (Surlyn $\left(\right.$ ) ) frame that melts at $100{ }^{\circ} \mathrm{C}$. The electrolytes used consisted of $0.5 \mathrm{M}$ 1-butyl-3-methylimidazolium iodide (BMII), 0.1 M lithium iodide, $0.05 \mathrm{M}$ iodine and 0.5 M tert-butylpyridine in acetonitrile.

\subsection{Device characterization}

The $I V$ characteristics of cells were measured using a Sun 2000 Solar Simulator ( $150 \mathrm{~W}$, ABET Technologies). The illumination intensity was measured to be $100 \mathrm{~mW} \mathrm{~m}^{-2}$ with a calibrated silicon photodiode. The appropriate filters were utilized to faithfully simulate the AM 1.5G spectrum. The applied potential and cell current were measured with a Keithley 2400 digital source meter. The IPCE (Incident Photon to Current conversion Efficiency) was measured using a home made set up consisting of a $150 \mathrm{~W}$ Oriel Xenon lamp, a motorized monochromator and a Keithley 2400 digital source meter.

Transient photovoltage (TPV) and charge extraction (CE) measurements were carried out on a system as reported earlier by our own group. ${ }^{{ }^{\mathrm{at}}}$ In the CE measurements, white light from a series of LEDs was used as the light source. When the LEDs are turned off the cell is immediately short circuited and the charge is extracted allowing calculation of electron density in the cells. By changing the LED intensity the electron density can be estimated as a function of cell voltage. In TPV measurements, in addition to the white light applied by the LEDs, a constant background voltage is applied to the cells and again, a diode pulse $(660 \mathrm{~nm}$, $10 \mathrm{~mW}$ ) is then applied to the sample inducing a change of $2-3 \mathrm{mV}$ within the cell voltage.

The resulting photovoltage decay transients are collected and the $\tau$ values are determined by fitting the data to a first order decay (equation $\exp (-t / \tau)$ ).

Laser-transient absorption spectroscopy (L-TAS) measurements were similar to those carried out previously. ${ }^{\text {tb }}$ The kinetics were recorded in a blank electrolyte consisting of 0.5 M tert-butylpyridine in acetonitrile and the iodide/tri-iodide electrolyte used for the optimized $0.16 \mathrm{~cm}^{2}$ devices. 


\subsection{Theoretical calculations}

The molecules were optimized with the Gaussian09 code. $\frac{8}{\text { The functional of choice was }}$ B3LYP ${ }^{2}$ and the basis set was $6-31 G(d)$. ${ }^{10}$ The frontier molecular orbitals were plotted at the same density isovalue.

\section{Results and discussion}

In Fig. 3 we can see the UV-visible absorption spectra for the LCVC01, LCVC02 and LCVC03 dyes. Their photophysical and electrochemical characteristics are listed in Table 1.

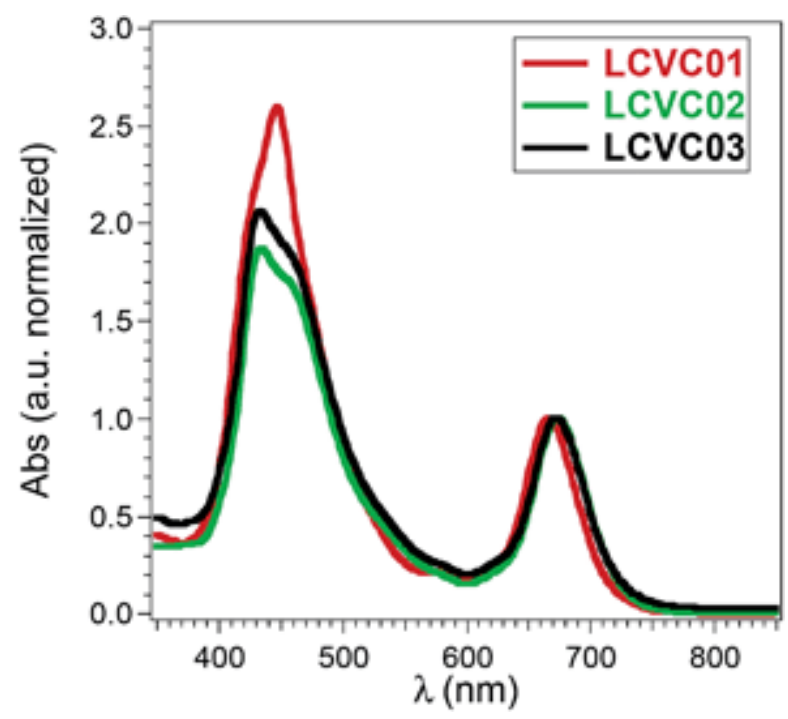

Fig. 3 UV-visible absorption spectra of LCVC01, LCVC02 and LCVC03 in THF.

Table 1 Absorption, emission and electrochemical properties of LCVC01, LCVC02 and LCVC03

\begin{tabular}{lllllll} 
Dye & $\lambda_{\text {abs }}(\mathbf{n m})$ & $\lambda_{\text {em }}(\mathbf{n m})$ & $\boldsymbol{E}_{\text {ox }}\left(\mathbf{V} v \mathbf{s .} \mathbf{F c} / \mathbf{F c}^{+}\right)$ & $\boldsymbol{E}_{\mathbf{0 - 0}}(\mathbf{e V})$ & $\boldsymbol{E}_{\text {номо }}(\mathbf{e V})$ & $\boldsymbol{E}_{\text {LUMо }}(\mathrm{eV})$ \\
\hline LCVC01 & $448 ; 579 ; 668$ & 705 & 0.19 & 1.82 & -5.07 & -3.25 \\
LCVC02 & $434 ; 674$ & 715 & 0.17 & 1.81 & -5.05 & -3.24
\end{tabular}




\begin{tabular}{|c|c|c|c|c|c|c|}
\hline Dye & $\lambda_{\text {abs }}(\mathbf{n m})$ & $\lambda_{\mathrm{em}}(\mathrm{nm})$ & $E_{o x}\left(\mathrm{~V} v s . \mathrm{Fc} / \mathrm{Fc}^{+}\right)$ & $E_{0-0}(\mathrm{eV})$ & $E_{\text {номо }}(\mathbf{e V})$ & $E_{\text {LUMO }}(\mathrm{eV})$ \\
\hline LCVC03 & $434 ; 674$ & 690 & 0.17 & 1.82 & -5.05 & -3.23 \\
\hline \multirow{2}{*}{\multicolumn{7}{|c|}{$\begin{array}{l}a \text { Measured in tetrahydrofuran. In parenthesis molar extinction efficient at } \lambda_{\text {abs }}\left(\mathrm{in} \mathrm{M}^{-1} \mathrm{~cm}^{-1}\right) . b \text { Measured in } 0.1 \mathrm{M} \text { tetrabutylammonium } \\
\text { hexafluorophosphate in THF at a scan rate of } 10 \mathrm{mV} \mathrm{s}{ }^{-1} \text {. The working electrode consisted of a platinum wire and the counter electrode a platinum }\end{array}$}} \\
\hline & & & & & & \\
\hline \multicolumn{7}{|c|}{ mesh. The reference electrode was the silver calomel electrode (saturated $\mathrm{KCl}$ ). All solutions were degassed with argon for 5 minutes prior t } \\
\hline
\end{tabular}

As shown in Fig. 3 all the dyes exhibit typical porphyrin spectra with the bands associated with them. Centred at $\lambda=450 \mathrm{~nm}$ we observe an intense Soret band and between 600 and 700 $\mathrm{nm}$ a less intense Q-band.

The oxidation potentials of porphyrins were measured by cyclic voltammetry in THF. LCVC02 and LCVC03 present the same oxidation potential. However, the potential is $20 \mathrm{mV}$ lower when compared to that of LCVC01. This is due to the presence of the thiophene and the furan moieties, between the BDT group and the carboxylic acid

in LCVC02 and LCVC03respectively.

We do not observe a great difference in the HOMO and LUMO energy levels between the molecules. The HOMO energy value ensures efficient dye regeneration by the electrolyte and the LUMO energy value is high enough to make possible efficient electron transfer from the dye excited state into the $\mathrm{TiO}_{2}$ conduction band $\left(E_{\mathrm{TiO} 2}=-4.0 \mathrm{eV}\right)$.

By comparing the theoretical frontier orbitals between the three molecules we observed that the highest occupied molecular orbital (HOMO) of the three dyes lies predominantly on the donor moiety of the molecule. The lowest unoccupied molecular orbital (LUMO) is similar for LCVC02 and LCVC03 showing a significant shift through the acceptor due to the presence of the BDT acting as an electron drawing moiety that we do not observe for the LCVC01 dye. Taking into account this observation we can explain the higher charge transfer characteristics of the LCVC02 and LCVC03 porphyrins. The main difference between LCVC02 and LCVC03 is the larger contribution of the 3p orbital of S in LCVC02 to the LUMO (Fig. 4). 


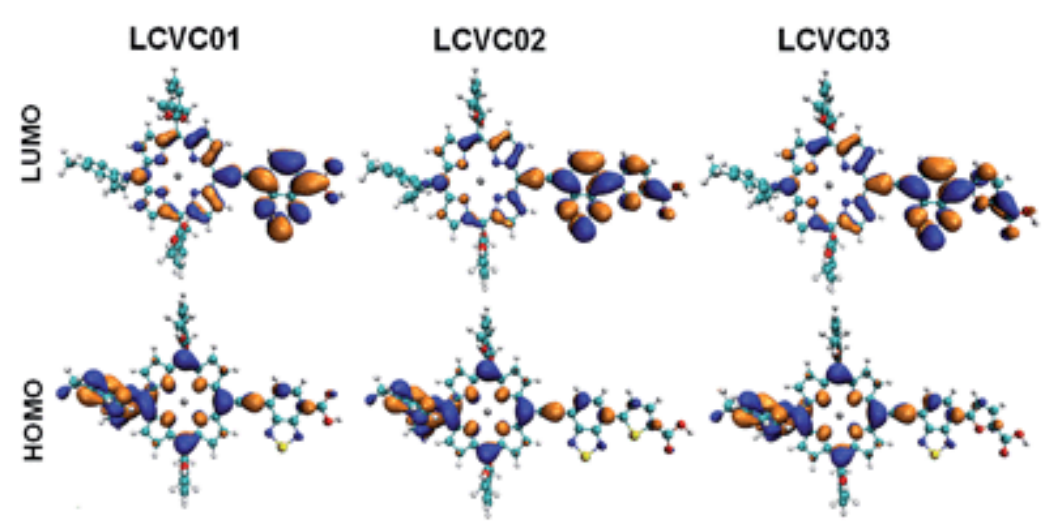

Fig. 4 Frontier molecular orbitals of LCVC01, LCVCO2 and LCVC03 at the B3LYP/6-31G(d) level.

In addition the dyes present different dipolar moments (Table 2). For LCVC01 a large dipole value aligned parallel $\left(\mu_{x}\right)$ to the carboxylate anchoring group can induce a severe band-shift (upwards) when adsorbed on the surface, thus hindering charge injection. LCVC03 presents a large component out of the plane of the porphyrin ring $\left(\mu_{z}\right)$ that induces dipole-dipole interactions in the dye layer. LCVC02 thus presents a compromise minimizing the dipole contributions that can compromise injection.

Table 2 Dipole moment of the dye molecules, Cartesian components and module

\begin{tabular}{lcccc} 
Porphyrin & $\boldsymbol{\mu}_{x}(\mathbf{D})$ & $\boldsymbol{\mu}_{y}(\mathbf{D})$ & $\boldsymbol{\mu}_{z}(\mathbf{D})$ & $|\boldsymbol{\mu}|(\mathbf{D})$ \\
\hline LCVC01 & 5.15 & -0.48 & -0.05 & 5.17 \\
LCVC02 & 4.68 & 2.95 & -0.27 & 5.54 \\
LCVC03 & 3.00 & 3.06 & -1.00 & 4.40
\end{tabular}

LCVC01, LCVC02 and LCVC03 were used to fabricate DSSC solar cells and measured under illumination conditions (AM $1.5 \mathrm{G} 100 \mathrm{~mW} \mathrm{~m}^{-2}$ ). The device properties are listed inTable 3. 
Table 3 Solar cell parameters for our best-measured devices

\begin{tabular}{lllll} 
Porphyrin & $\boldsymbol{V}_{\text {oc }}(\mathbf{V})$ & $\boldsymbol{J}_{\text {sc }}\left(\mathbf{m A ~ c m}^{-2}\right)$ & FF (\%) & Efficiency $^{\underline{a}}(\boldsymbol{\%})$ \\
\hline LCVC01 & 0.65 & 7.69 & 75 & $3.84(4.52)$ \\
LCVC02 & 0.70 & 20.00 & 74 & $10.41(12.1)$ \\
LCVC03 & 0.58 & 5.81 & 76 & $2.55(2.88)$
\end{tabular}

$a$ Efficiencies recorded with a mask. In parenthesis the efficiency values without a mask.

The photocurrent density observed for LCVCO1 and LCVCO3 is lower when compared to that of LCVC02. The best $J_{\mathrm{sc}}$ corresponds to LCVCO2 that displays an impressive $20.00 \mathrm{~mA} \mathrm{~cm}^{-2}$; such current is actually as high as those of most MAPI solar cells, in contrast with the 7.7 and 5.8 achieved for LCVCO1 and LCVCO3 respectively. The measured photocurrent matches the calculated photocurrent after integration of the IPCE spectrum (Fig. 5b) against the 1.5 AMG solar spectrum provided by NREL lab (Excel file in the ESI + ) with a $5 \%$ error due to the mismatch factor of our solar simulator. The open circuit voltage $\left(V_{\text {oc }}\right)$ for LCVC01 is $650 \mathrm{mV}$. As reported before the introduction of a spacer group between the BDT and the anchoring group, as in the case of LCVCO2, leads to a substantial increase in $V_{o c}$. However, in our case, this effect is not observed for LCVC03 with a $V_{o c}$ as low as $580 \mathrm{mV}$. Yet, all solar cells present similar values for the fill-factor (FF). 

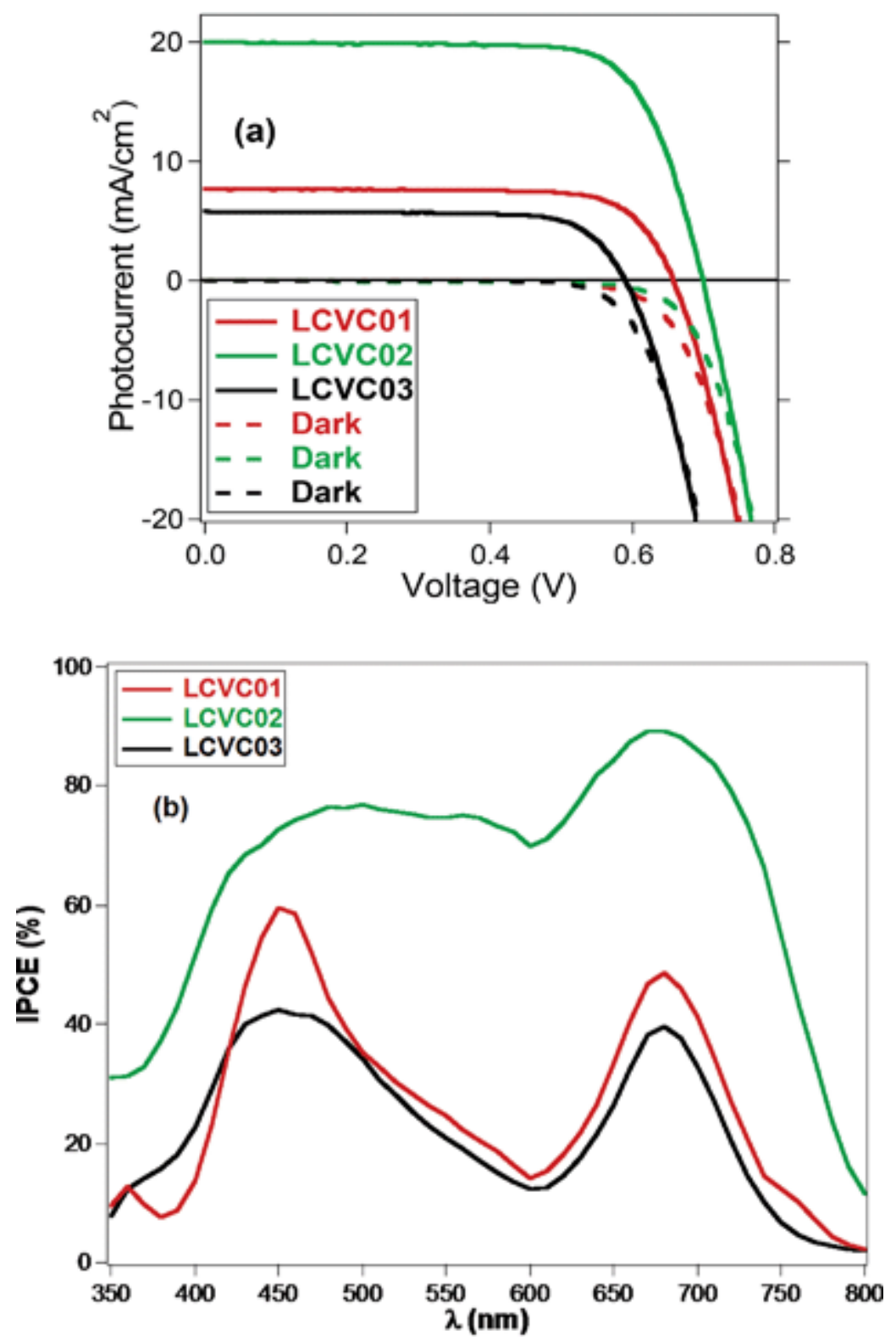

Fig. 5 (a) I-V curves for LCVC01, LCVC02 and LCVC03; and (b) IPCE spectra

ofLCVC01, LCVC02 and LCVC03. DSSC devices recorded under AM 1.5G radiation. The dashed lines correspond to the $I V$ dark curves.

In Fig. 5a we represent the $I-V$ curves for LCVC01, LCVC02 and LCVC03. Fig. $\underline{5 b}$ illustrates the incident-photon-to-current conversion efficiency (IPCE) of our champion cells made using porphyrins LCVC01, LCVCO2 and LCVC03. The IPCE spectrum values for LCVC02 showed two maxima corresponding to the Soret and Q bands of the porphyrin at $480 \mathrm{~nm}(76 \%)$ and $670 \mathrm{~nm}(90 \%)$.

The electron density (defined as the number of electrons accumulated at the $\mathrm{m}-\mathrm{TiO}_{2}$ ) and the electron lifetime (Fig. 6a and b) were probed using charge extraction and transient photovoltage measurements respectively. We observed higher charge (electron) density for LCVCO2 when compared to that of LCVC01. However a larger difference is observed when we compare to LCVC03 that presents a much lower charge density. Moreover, a clear 
shift of the exponential curve from 0.5 to $0.6 \mathrm{~V}$ can be seen for LCVC03. This shift can be correlated with a shift of the $\mathrm{TiO}_{2}$ conduction band edge that leads to a decrease in the photoinjection yield of electrons from the dye-excited state, and therefore the device photocurrent. The $\mathrm{TiO}_{2}$ conduction band shift has been previously reported to occur by changes at the surface of the $\mathrm{TiO}_{2}$ due to different dipoles, and protonation or addition of, for example, tertbutyl pyridine at the liquid electrolyte as an additive to enhance the device $V_{\text {oc }}$ at the expense of the device photocurrent. In our case, it is probably due to the large $\mu_{x}$ component of the dye. From the TPV measurements (Fig. 6b), slower recombination dynamics can be seen for LCVC02 and a similar electron lifetime is also observed for LCVC01, which explains the similar voltage achieved for these devices, which is in agreement with the shortest electron lifetime for LCVC03 too. The differences obtained can be attributed to the differences in the e- $\mathrm{TiO}_{2} /$ electrolyte ${ }^{+}$recombination rate. Several studies reported before by our group and others show that this experimental observation is true for organic sensitizers ${ }^{11}$ and ruthenium complexes..$^{12}$ Due to this, more species, $\mathrm{I}_{2}$ according to O'Regan and co-workers, $\stackrel{13}{ }$ are present at the $\mathrm{TiO}_{2}$ surface accelerating the recombination rate. In our present study, we have seen how this hypothesis effects a change in the device performance by just the change of only one atom in the molecular structure. 

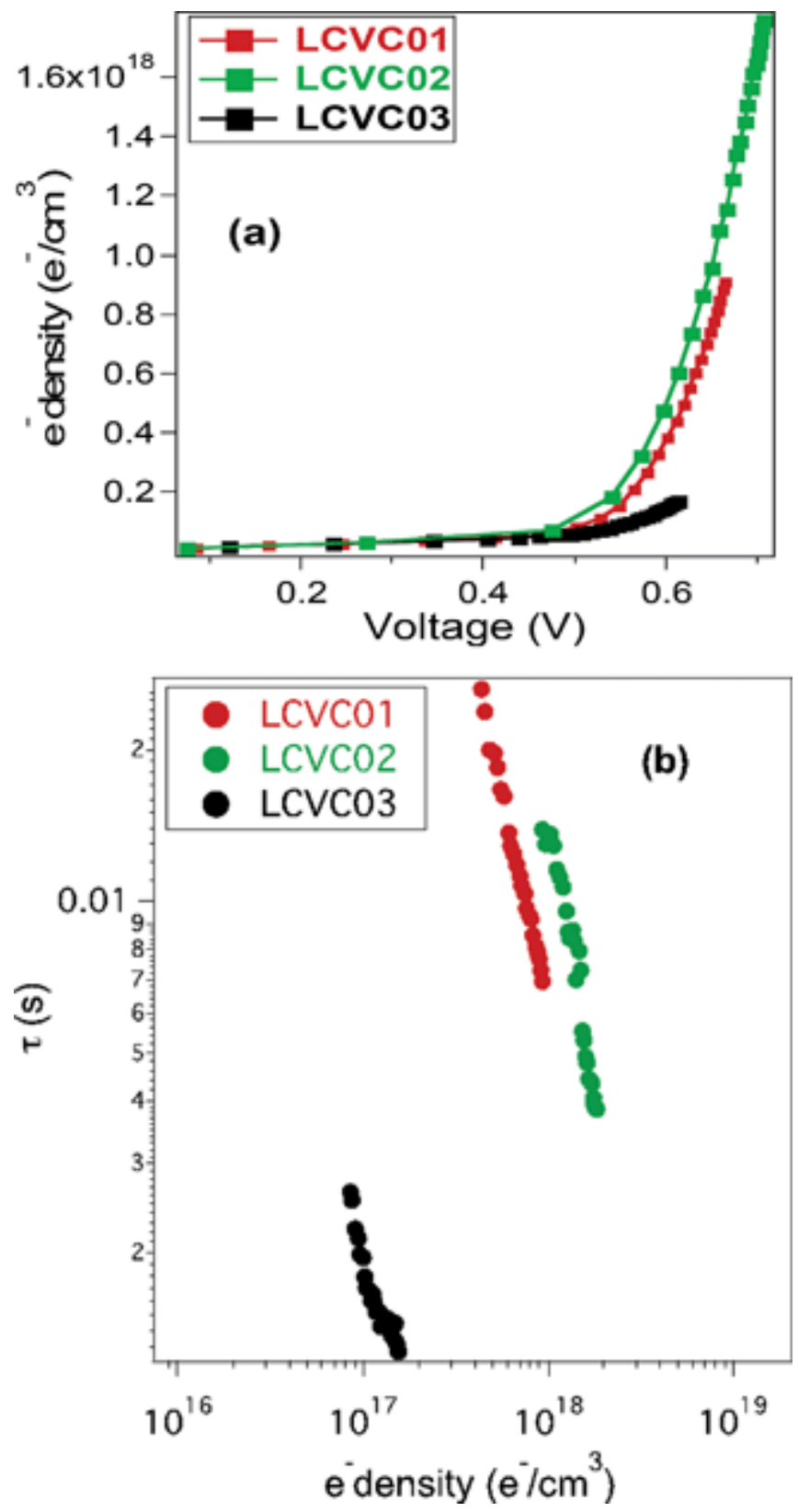

Fig. 6 (a) Electron density as a function of cell voltage and (b) electron density as a function of cell voltage for LCVC01, LCVC02 and LCVC03 devices. 
Yet, we must also demonstrate that differences observed between the porphyrins are not due to differences in the regeneration kinetics. In order to probe dye ground state regeneration by the $\mathrm{I}_{3}^{-} / \mathrm{I}^{-}$redox couple we employed laser transient absorption spectroscopy (L-TAS).

In Fig. 7 we can see the charge recombination decays between the photo-injected electrons at the $\mathrm{TiO}_{2}$ and the oxidized dye for $\mathrm{LCVC01}, \mathrm{LCVCO2}$ and $\mathrm{LCVC03}$ respectively. The data were recorded in the absence of the electrolyte (black) and correspond to the long-lived decays assigned to the dye cation formed following photo-excitation. Using red color we monitored the same process but in the presence of an electrolyte. As can be seen the kinetics for the dye cation disappearance is much faster due to the regeneration by $\mathrm{I}^{-}$. To estimate the regeneration efficiency we quantified the lifetime at the FWHM (full width at half maximum) of the signal, in red, which is within the same millisecond time scale for all three different solar cells withLCVC01, LCVC02 and LCVC03 showing marginal differences which cannot account for the large differences observed for the devices under sun-simulated standard illumination conditions 

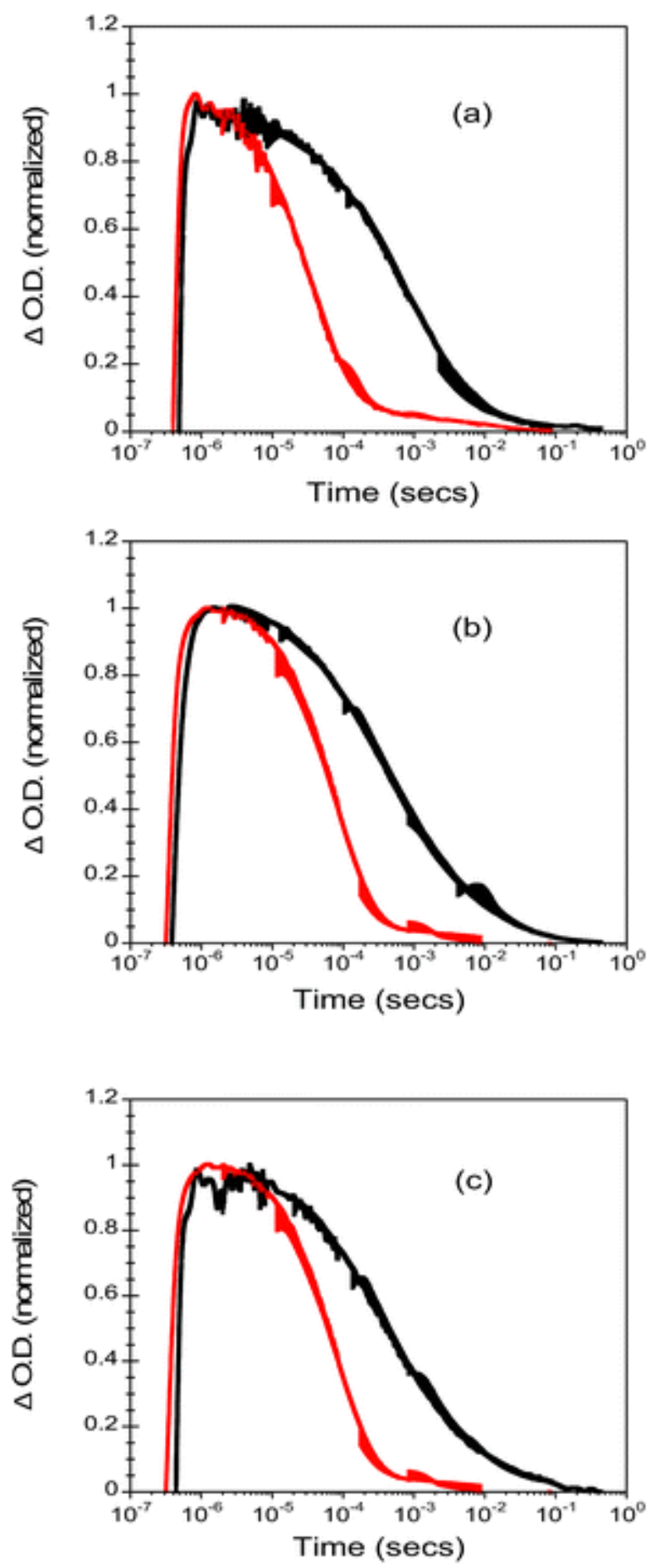

Fig. 7 Transient absorption kinetics of (a) LCVC01, (b) LCVCO2 and (c) LCVCO3 recorded for $1 \mathrm{~cm}^{2}$ area devices comprising $8 \mu \mathrm{m} \mathrm{TiO}$ films in the presence of a blank electrolyte (black) and an iodide/tri-iodide red/ox electrolyte (red). Kinetics were recorded at $825 \mathrm{~nm}$ forLCVC01, $775 \mathrm{~nm}$ for LCVC02 and $825 \mathrm{~nm}$ for LCVC03 following excitation at $600 \mathrm{~nm}$. 


\section{Conclusions}

We synthesized a new series of push pull porphyrins using a diphenylamine as a donor moiety and an acid group as the anchoring group with the introduction of a BDT group between the porphyrin core and the anchoring group for $\mathbf{L C V C 0 1}$ and the introduction of a thiophene and a furan between the BDT and the anchoring group for $\mathrm{LCVCO2}$ and $\mathrm{LCVCO3}$ dyes. The DSSC performance gave us a record cell of $10.4 \%$ for LCVC02; however only $3.84 \%$ and $2.55 \%$ were achieved for $\mathbf{L C V C 0 1}$ and $\mathbf{L C V C O 3}$ respectively. As we have studied in the past the thiophene introduced in $\mathbf{L C V C O 2}$ reduces the recombination reaction. However, the introduction of a furan moiety does not cause the same effect. In that case, the major effect is the decrease in photocurrent. Moreover, from the charge extraction measurements a clear change of the $\mathrm{TiO}_{2}$ conduction band edge can be registered that can be the consequence of a change of the dye dipole at the surface leading to a lower electron injection yield in good agreement with the lower measured photocurrent. Therefore, in a dye design dipole descriptors shall be incorporated. Further work is being done in this direction.

\section{Acknowledgements}

EP would like to thank MINECO for the project CTQ2013-47183-R and the support through Severo Ochoa Excellence Accreditation 2014-2018 (SEV-2013-0319).

\section{References}

$1 \mathrm{~S}$. Mathew, A. Yella, P. Gao, R. Humphry-Baker,

F. E. CurchodBasile, N. Ashari-Astani, I. Tavernelli,

U. Rothlisberger, M. K. Nazeeruddin and M. Gratzel, Nat. Chem., 2014, 6, 242-247.

2 H. J. Snaith, Adv. Funct. Mater., 2010, 20, 13-19.

3 T. Bessho, S. M. Zakeeruddin, C.-Y. Yeh, E. W.-G. Diau and

M. Gr" atzel, Angew. Chem., Int. Ed., 2010, 49, 6646-6649.

4 A. Yella, H.-W. Lee, H. N. Tsao, C. Yi, A. K. Chandiran,

M. K. Nazeeruddin, E. W.-G. Diau, C.-Y. Yeh,

S. M. Zakeeruddin and M. Gratzel, Science, 2011, 334, 629-

634.

5 (a) Y.-C. Chang, C.-L. Wang, T.-Y. Pan, S.-H. Hong, C.-M. Lan, H.-H. Kuo, C.-F. Lo, H.-Y. Hsu, C.-Y. Lin and E. W.-G. Diau, Chem. Commun., 2011, 47, 8910-8912; (b) C.-H. Wu,

M.-C. Chen, P.-C. Su, H.-H. Kuo, C.-L. Wang, C.-Y. Lu,

C.-H. Tsai, C.-C. Wu and C.-Y. Lin, J. Mater. Chem. A, 2014, 
2, 991-999; (c) Y. Wang, B. Chen, W. Wu, X. Li, W. Zhu, H. Tian and Y. Xie, Angew. Chem., Int. Ed., 2014, 53, 1077910783; (d) L. Pelleja, C. V. Kumar, J. N. Clifford and E. Palomares, J. Phys. Chem. C, 2014, 118, 16504-16509; (e) M. Tanaka, S. Hayashi, S. Eu, T. Umeyama, Y. Matano and H. Imahori, Chem. Commun., 2007, 2069-2071.

6 (a) L. Zhao, P. Wagner, A. B. S. Elliott, M. J. Griffith, T. M. Clarke, K. C. Gordon, S. Mori and A. J. Mozer, J. Mater. Chem. A, 2014, 2, 16963-16977; (b) M. J. Griffith, K. Sunahara, P. Wagner, K. Wagner, G. G. Wallace, D. L. Officer, A. Furube, R. Katoh, S. Mori and A. J. Mozer, Chem. Commun., 2012, 48, 4145-4162.

7 (a) D. Joly, L. Pellej, S. Narbey, F. Oswald, J. Chiron, J. N. Clifford, E. Palomares and R. Demadrille, Sci. Rep., 2014, 4; (b) J. Clifford, A. Forneli, L. Lopez-Arroyo, R. Caballero, P. de la Cruz, F. Langa and E. Palomares, ChemSusChem, 2009, 2, 344-349.

8 M. J. Frisch, et al., Gaussian 09 Revision D.01, Gaussian. Inc., Wallingfrod CT, 2009.

9 P. J. Stephens, F. J. Devlin, C. F. Chabalowski and M. J. Frisch, J. Phys. Chem., 1994, 98, 11623-11627. 10 V. A. Vassolov, J. A. Pople, M. A. Ratner and T. L. Windus, J. Chem. Phys., 1998, 109, 1223-1229.

11 (a) M. Planells, L. Pelleja, J. N. Clifford, M. Pastore, F. De Angelis, N. Lopez, S. R. Marder and E. Palomares, Energy Environ. Sci., 2011, 4, 1820-1829; (b) J.-I. Nishida, T. Masuko, Y. Cui, K. Hara, H. Shibuya, M. Ihara, T. Hosoyama, R. Goto, S. Mori and Y. Yamashita, J. Phys. Chem. C, 2010, 114, 17920-17925; (c) B. C. O'Regan, I. Lopez-Duarte, M. V. Martinez-Diaz, A. Forneli, J. Albero, A. Morandeira, E. Palomares, T. Torres and J. R. Durrant, J. Am. Chem. Soc., 2008, 130, 2906-2907.

12 (a) K. Hu, H. A. Severin, B. D. Koivisto, K. C. D. Robson, E. Schott, R. Arratia-Perez, G. J. Meyer and C. P. Berlinguette, J. Phys. Chem. C, 2014, 118, 1707917089; (b) A. Reynal, A. Forneli, E. Martinez-Ferrero, A. Sanchez-Diaz, A. Vidal-Ferran, B. O'Regan and E. Palomares, J. Am. Chem. Soc., 2008, 130, 13558-13567. 13 C. E. Richards, A. Y. Anderson, S. Martiniani, C. Law and B. C. O'Regan, J. Phys. Chem. Lett., 2012, 3, 1980-1984. 